\title{
Study of trace metal contamination and ecological risk assessment in the sediments of a tropical river estuary, Southwestern India
}

\author{
D'Souza Nishitha · Vadakkeveedu Narayan Amrish • Kumar Arun • \\ Anish Kumar Warrier · Harikripa Narayana Udayashankar • \\ Keshava Balakrishna
}

Received: 10 June 2021 / Accepted: 23 December 2021 / Published online: 14 January 2022

(C) The Author(s) 2022, corrected publication 2022

\begin{abstract}
The present study aims to assess the extent of trace metal pollution in the sediments of SitaSwarna estuary, west coast of India, and investigate their possible ecological risk on the aquatic environment. The sediment cores were analyzed for sand, silt, clay, organic carbon, and trace metals (Al, Fe, Mn, $\mathrm{As}, \mathrm{Cd}, \mathrm{Co}, \mathrm{Zn}, \mathrm{Pb}, \mathrm{Ni}, \mathrm{Cr}$, and $\mathrm{Cu}$ ) at 2-cm intervals. The study revealed that sediments have deposited in relatively violent to very violent hydrodynamic energy conditions. Factor analysis indicated that the metal distribution is mainly controlled by Fe-Mn oxyhydroxides and organic carbon. Further, the geochemical approach, pollution indices, and statistical evaluation revealed moderate pollution in the catchment. From an ecotoxicological perspective, the estimated risk index (RI) value was found to less than 150, indicating low risk for aquatic life. Thus, this baseline study would help to adopt strategies in pollution control and protect the fragile marine environment.
\end{abstract}

Keywords Estuarine sediments · Metals $\cdot$ Particle size distribution $\cdot$ Pollution $\cdot$ Risk index $\cdot$ Southwest India

D. Nishitha - V. N. Amrish · K. Arun - A. K. Warrier ·

H. N. Udayashankar · K. Balakrishna $(\bowtie)$

Department of Civil Engineering, Manipal Institute

of Technology, Manipal Academy of Higher Education,

Manipal, India

e-mail: k.balakrishna@manipal.edu

\section{Introduction}

Civilization is often associated with rivers and coastal ecosystems from the past to the present. Specifically, estuaries are of global importance because they are viewed as highly productive zones and sustain unique plant and animal populations (Gredilla et al., 2015). However, with the rising pollution of the fluvial and coastal ecosystems, the current scenario alarms humanity and marine life (Bingöl et al., 2013; Fernandes et al., 2008; Tavakoly Sany et al., 2014; Zahra et al., 2014). Due to their non-degradability and ability to bioaccumulate in the food chain, metal pollution has become a global problem and gaining the prime attention of the decision-makers (Bastakoti et al., 2019; Ergül et al., 2013; Prajith et al., 2016; Xavier et al., 2020). Hence investigation of biogeochemistry of rivers and estuaries provides insights to the trace metal toxicity and its bioavailability for the well-being of aquatic biota. Furthermore, estuaries are very dynamic environments that can significantly alter the amount of organic and inorganic pollutants entering the coastal environment before depositing into the deep sea and mixing with the marine sediments. Changes in the ionic strength, $\mathrm{pH}$, velocity of the water, and the ratios of divalent cations result in the flocculation of finer particles. The finer ones eventually end up in the bottom sediments, which are known as contaminant sinks. Thus, sediments are the most significant pools for trace metals (Zhang et al., 2015; Zhao et al., 2017). 
On the other hand, contaminated sediments will not remain at the bottom perpetually; varying hydrodynamic conditions and geochemical processes lead to resuspension of contaminants between sediments and water column, which can adversely affect the aquatic life (Atkinson et al., 2007; Hu et al., 2013). There are many factors such as grain size (Fernandes \& Nayak, 2016; Mokwe-Ozonzeadi et al., 2019; Nasnodkar \& Nayak, 2015), organic matter (Ghosh et al., 2016), mangroves (Bastakoti et al., 2019; Xavier et al., 2020), and hydrodynamic conditions (Dessai et al., 2009; Liu et al., 2019) in regulating the deposition and distribution of trace metals. Also, sediments are significant in archiving past environmental and climate-related changes (Ahmed et al., 2018; Alharbi et al., 2019); thus, it is possible to predict the past contamination vis-à-vis the present situation. Timely investigation of metal pollution in the rivers, estuaries, and the adjacent coastal environments will determine the magnitude of pollution levels (Cyriac et al., 2021; Mitra et al., 2018).

Though tropical rivers account for greater than $60 \%$ of the water and sediment discharge to the world oceans (Gaillardet et al., 1995), very few studies exist on the dissolved trace metal behavior in the estuarine environment of tropics (Alagarsamy, 2006; Cyriac et al., 2021; Satapathy \& Panda, 2015). Specific to Sita-Swarna rivers, only two studies are documented as-on-date (Nishitha et al., 2019; Tripti et al., 2013). Hence to fill the gap in the literature, this study has been taken up in the estuarine environment of Sita-Swarna. With this overview, we have attempted an in-depth study to understand the factors controlling the distribution pattern of the metals in the Swarna estuary. The banks of the Swarna are densely populated and have a major fishing harbor (Malpe) of Karnataka coast. In the future, this study can be used to compare the varying heavy metal pollution with time, in the catchment. Policy makers will benefit from the data reported, for framing future pollution mitigation strategies.

The main objective of the work is (i) to study the down core variations of the metals, (ii) to study the influence of grain size in the deposition of metals, and (iii) to assess the sediment quality using various geochemical indices.

\section{Study area}

The study area (Fig. 1) lies between $13^{\circ} 23^{\prime} 30^{\prime \prime} \mathrm{N}$ and $13^{\circ} 28^{\prime} 30^{\prime \prime} \mathrm{N}$ latitudes and between $74^{\circ} 41^{\prime} 55^{\prime \prime} \mathrm{E}$ and $74^{\circ} 45^{\prime} 00^{\prime \prime} \mathrm{E}$ longitudes. The estuary remains freshwater dominated during the southwest monsoon (June to September) and saline during the rest of the year. The water levels during the neap period range from 0.5 to $1.0 \mathrm{~m}$ (low) and from 1.0 to $1.5 \mathrm{~m}$ (high), respectively. The waves along the coast are low during pre-monsoon and post-monsoon, with a wave height of $\sim 1.2 \mathrm{~m}$ and $1.4 \mathrm{~m}$, respectively. In contrast, it reaches a maximum of $4 \mathrm{~m}$ during the southwest monsoon in the western direction (Avinash et al., 2012).

\section{Materials and methods}

Raising and subsampling of sediment core

Two shallow cores were collected from the SitaSwarna estuary, one upstream near the mangrove vegetation (Core $\mathrm{A}-70 \mathrm{~cm}$ ) and one downstream near the mudflat (Core B $-76 \mathrm{~cm}$ ) (Fig. 1). The cores were collected by manually pushing a PVC pipe into the sediment bed during the low-tide conditions. The cores were labeled, packed, and stored in cold storage (at $4{ }^{\circ} \mathrm{C}$ ) for further analysis. Later, both the cores were subsampled at $2-\mathrm{cm}$ intervals using a plastic knife to avoid metal contamination. Subsamples were transferred to zip lock polyethylene bags and stored for further analysis. Visually, core A was grey in color and core B brownish.

Digestion of sediments for metal analysis

The wet sediment samples were oven-dried at a temperature of less than $60{ }^{\circ} \mathrm{C}$. Later, the dried samples were sieved to obtain the fine fraction $(<63 \mu \mathrm{m})$. Approximately $0.1 \mathrm{~g}$ of sediment was weighed and transferred to Teflon beakers. An acid mixture of $2 \mathrm{~mL}$ of Merck Suprapur ${ }^{\circledR} \mathrm{HF}$ (40\%), $5 \mathrm{~mL}$ of $\mathrm{HNO}_{3}(65 \%)$, and $2 \mathrm{~mL}$ of $\mathrm{HCl}(35 \%)$ was added to the sediment sample (Suja et al., 2017). Further, the samples were transferred onto a hot plate and kept for digestion. Initially, the temperature was maintained at $90{ }^{\circ} \mathrm{C}$ for $2 \mathrm{~h}$ and later decreased to $60{ }^{\circ} \mathrm{C}$ until the samples evaporated to dryness. The residue was dissolved in $0.1 \mathrm{~N} \mathrm{HNO}_{3}$. This was repeated 2 to 3 times to remove excess HF present in the samples. Finally, the residue was made up to $25 \mathrm{~mL}$ using $0.1 \mathrm{~N} \mathrm{HNO}_{3}$ and transferred to 


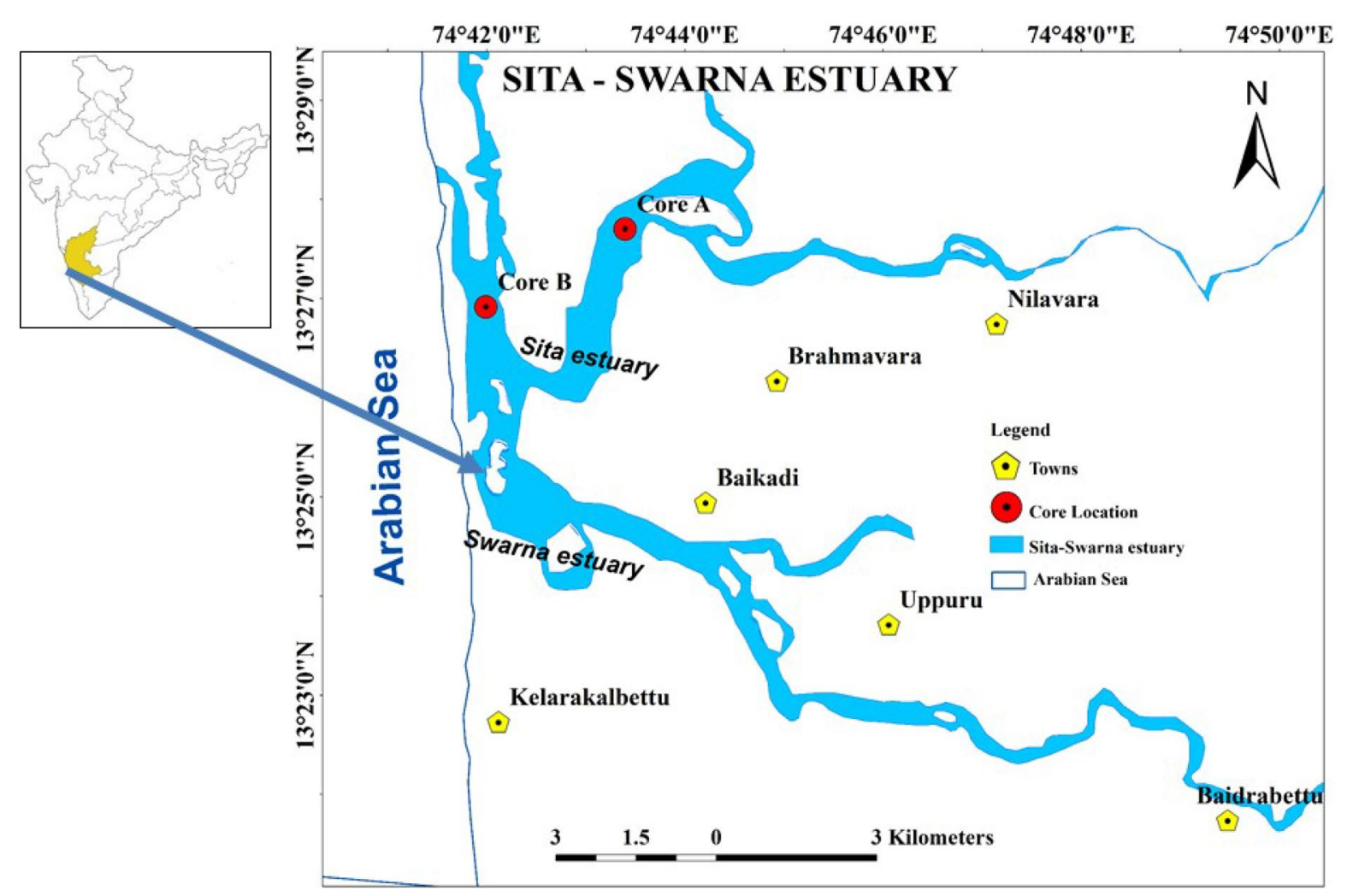

Fig. 1 Map showing the core locations in the Sita-Swarna estuary (modified map from Nishitha et al. (2021)

cleaned PP bottles. The digested samples were preserved in cold storage at $4{ }^{\circ} \mathrm{C}$. Digestion was performed in a fume hood; extreme care was taken to avoid any metal contamination. Further, samples were analyzed for metals using ICP-OES Thermo fisher ICAP 7000 series available at the Department of Civil Engineering, Manipal Institute of Technology. The repeatability of the samples was checked by analyzing the duplicates and known concentration standards. One control standard was placed in the sample analysis sequence for every ten samples. The accuracy of the measurements was ensured by running a certified estuarine reference standard, BCR®-667. The certified standard was digested and run along with the samples. The accuracy and precision of the measurements were $<6 \%$ and $5 \%$, respectively. Further multivariate statistical analysis was performed using the Statistical Package for the Social Sciences (SPSS)-v.21. Also, factor analysis (FA) with principal component extraction and Kaiser normalized varimax rotation was performed on the data sets.

\section{Grain size analysis}

Approximately $10 \mathrm{~g}$ of oven-dried (at $60{ }^{\circ} \mathrm{C}$ ) sediment samples were used for particle size analysis. The organic matter and carbonates were removed by treating the sample with $30 \%$ hydrogen peroxide and $10 \%$ glacial acetic acid (Warrier et al., 2016). Later wet sieving was done using ASTM sieve size 230 (62- $\mu \mathrm{m}$ pore diameter) to separate the sand fraction in the sample. After removing the sand fraction, the silt and clay fraction mixture was transferred to a graduated cylinder. To prevent the flocculation of the particles, the deflocculating agent $20 \mathrm{~mL}$ of sodium hexametaphosphate (Calgon) was added. By using the conventional method of pipette analysis, silt + clay was determined. The cylinder containing clay and silt was stirred vigorously for about 1 min using a long PVC pipe of 25-mm diameter. After $20 \mathrm{~s}$ of stirring, $20 \mathrm{~mL}$ of sample was pipetted out from $20-\mathrm{cm}$ depth. The collected suspensions were dried in an oven $\left(<100^{\circ} \mathrm{C}\right)$. The duplicate sample was collected before $40 \mathrm{~s}$ and analyzed for silt and clay fraction 
using a particle size analyzer available at the Geological Survey of India (GSI), Mangalore. The weight of the silt fraction was multiplied by a factor of 50 , and $1 \mathrm{~g}$ was subtracted from the value obtained to account for the Calgon solution that was added before. A similar procedure was followed for clay fractions. Dry sieving was carried out at half-phi intervals for the coarser particles retained on the +230 sieve $(5$, $10,18,35,60,120,+230$, and Pan). The sieves are assembled with coarser mesh at the top, followed by finer mesh and agitated using a mechanical shaker for $5 \mathrm{~min}$. Sieved individual fractions were weighed, and weight percentages calculated. Further, GStat, an inhouse software available at GSI, Mangalore, and the grain size distribution statistics were estimated.

\section{Contamination assessment methods}

Sediment assessment can be done using various methods. The most used ones are the geoaccumulation index and enrichment factor. The $I_{\text {geo }}$ was calculated to determine the degree of pollution in the sediments (Muller, 1969). The estimated concentrations were compared with the geochemical background values, i.e., average shale values given by Turekian and Wedopohl (1961). The results were interpreted using the following equation:

$I_{\text {geo }}=\left(\log _{2} \times\left(C_{n} / 1.5 \times B_{n}\right)\right)$

where $C_{n}$ is the element of interest and $B_{n}$ is the background value. A factor of 1.5 was used to account for the lithological variations for geochemical background values. Similarly, a normalized enrichment factor (Ergin et al., 1991) was applied to differentiate the source of origin from anthropogenic and natural means. This involved normalizing the sediments with conservative elements concerning reference elements such as $\mathrm{Al}, \mathrm{Fe}, \mathrm{Ti}$, and $\mathrm{Mn}$. In the current study, normalization was done with metal $\mathrm{Al}$ using the average shale value given by Turekian and Wedopohl (1961). The following equation calculated the Enrichment Factor (EF):

$\mathrm{EF}=\frac{(C / R) \text { Sample }}{(C / R) \text { World average shale }}$

where $(C / R)_{\text {Sample }}$ is the ratio of the concentration of element of interest $(C)$ to the reference element $(R)$ in the sediment samples and $(C / R)_{\text {average shale value }}$ is the ratio of the concentration of element of interest $(C)$ to the reference element $(R)$ in the geochemical background.

Further to evaluate the potential risk of trace metals on the ecosystem, ecological risk assessment was estimated by using the following equation given by Hakanson (1980):

$\left({ }^{i} \mathrm{Er}\right)={ }^{i} T_{r} \times{ }^{i} C_{f}={ }^{i} T_{r} \times\left({ }^{i} C_{o} /{ }^{i} C_{n}\right) ;$

$\mathrm{RI}=\sum_{i=1}^{7}{ }^{i} E r=\sum_{i=7}^{7} \operatorname{Tr} \times{ }^{i} C f$

where ${ }^{i} E_{r}$ is the ecological risk factor of metal " $i$ "; ${ }^{i} T_{r}$ and ${ }^{i} C_{f}$ are the toxic response factor and contamination factor for metal " $i$," respectively; and ${ }^{i} C_{o}$ and ${ }^{i} C_{n}$ are the concentrations measured for the metal " $i$ " in the sediment sample and its reference value. The values of ${ }^{i} T_{r}$ are $30,5,5,2,10$, and 1 for metals $\mathrm{Cd}, \mathrm{Cu}, \mathrm{Ni}, \mathrm{Pb}$, $\mathrm{Cr}$, As, and $\mathrm{Zn}$, respectively. Further, sediments were assessed for potential ecological risk using the standard values (Table 5) given by Hakanson (1980).

\section{Results and discussion}

Sediment characteristics and organic carbon

Descriptive statistics of various sediment components are given in Table 1 and downcore profiles of core A and core B are discussed separately in the following section.

Core A: The sand percentage varied from 53.74 to $89.58 \%$, with a mean ( \pm s.d.) value of $75.79 \%$ $( \pm 9.77 \%)$ in the upper estuary. Higher sand content was found in the core's surface layers (between 8 and $18 \mathrm{~cm}$ ) and the bottom layers (between 52 and $70 \mathrm{~cm}$ ), indicating that a relatively high hydrodynamic energy state existed, allowing coarser fractions to deposit more quickly. Sand content followed a decreasing trend and reached a minimum value of $53.74 \%$ at $26 \mathrm{~cm}$ (Fig. 2), balanced by the higher silt percentage $(40.99 \%)$.

Similar behavior was noted at the layer $44 \mathrm{~cm}$; here silt was higher and sand content was low, which indicates a calmer environment with the low hydrodynamic 
Table 1 Descriptive statistics of various sediment components and trace metals $(\mu \mathrm{g} / \mathrm{g})$

\begin{tabular}{|c|c|c|c|c|c|c|c|c|}
\hline & \multicolumn{4}{|c|}{ Core A (u/s) } & \multicolumn{4}{|c|}{ Core B $(d / s)$} \\
\hline & Min & $\operatorname{Max}$ & Mean & SD & Min & $\operatorname{Max}$ & Mean & SD \\
\hline Sand $(\%)$ & 53.74 & 89.58 & 75.79 & 9.77 & 46.58 & 95.52 & 84.94 & 8.54 \\
\hline Silt (\%) & 8.20 & 40.99 & 20.14 & 8.52 & 0.31 & 40.47 & 9.69 & 7.07 \\
\hline Clay (\%) & 0.25 & 8.73 & 4.07 & 1.88 & 0.04 & 11.27 & 2.21 & 2.05 \\
\hline $\mathrm{OC}(\%)$ & 0.61 & 1.84 & 0.97 & 0.32 & 0.05 & 2.66 & 0.54 & 0.59 \\
\hline As & 6.87 & 19.86 & 14.13 & 3.77 & 4.65 & 14.90 & 8.31 & 1.97 \\
\hline $\mathrm{Cd}$ & 0.00 & 0.30 & 0.06 & 0.07 & 0.01 & 0.27 & 0.09 & 0.07 \\
\hline Co & 4.42 & 19.69 & 11.45 & 3.78 & 3.81 & 15.85 & 5.77 & 2.51 \\
\hline $\mathrm{Cr}$ & 20.35 & 82.26 & 51.62 & 14.30 & 14.03 & 65.27 & 21.12 & 10.13 \\
\hline $\mathrm{Cu}$ & 0.70 & 15.58 & 6.58 & 4.05 & 0.23 & 65.85 & 11.38 & 13.04 \\
\hline $\mathrm{Ni}$ & 8.98 & 38.43 & 22.00 & 7.18 & 5.44 & 30.51 & 8.38 & 4.96 \\
\hline $\mathrm{Pb}$ & 13.61 & 55.52 & 30.11 & 10.19 & 1.24 & 29.89 & 8.51 & 6.34 \\
\hline $\mathrm{Zn}$ & 32.57 & 380.37 & 193.38 & 124.00 & 21.77 & 158.52 & 68.08 & 34.25 \\
\hline $\mathrm{Al}$ & 2.10 & 10.27 & 4.24 & 1.92 & 1.58 & 3.75 & 2.12 & 0.47 \\
\hline $\mathrm{Fe}$ & 0.67 & 2.33 & 1.48 & 0.41 & 0.43 & 1.70 & 0.62 & 0.26 \\
\hline $\mathrm{Mn}$ & 0.00 & 0.02 & 0.01 & 0.00 & 0.00 & 0.01 & 0.01 & 0.00 \\
\hline
\end{tabular}

Figure 3 is a ternary plot displaying the per cent data of sand, silt, and clay that helps understand the particle size distribution in the depositional environment

\section{Core A}

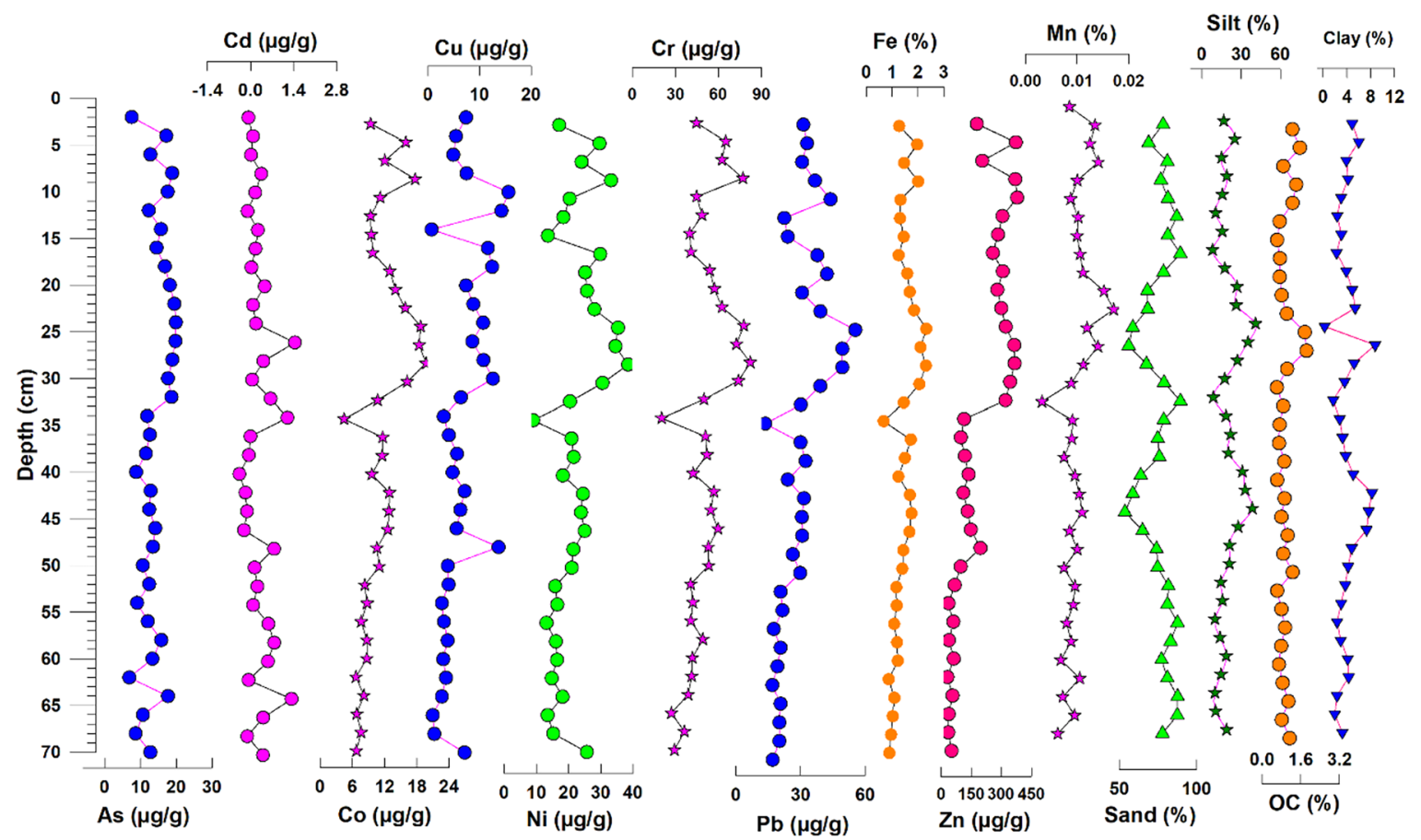

Fig. 2 Down core variations of sediment components and trace metals in core A (upstream) estuary 
(Perjup, 1988). From Fig. 3, it is revealed that their deposition took place in relatively violent to very violent hydrodynamic energy conditions.

The quantity of silt varied from 8.2 to $40.9 \%$, with a mean ( \pm s.d.) value of $20 \%( \pm 8.52)$. At depths of $24 \mathrm{~cm}$ and $42 \mathrm{~cm}$, the silt percentage reached the maximum value $(40.99 \%)$. Percent clay varied from 0.25 to $8.8 \%$, with a mean ( \pm s.d.) value of $4.07 \%$ $( \pm 1.88)$. Similarly, organic carbon ranged from 0.61 to $1.84 \%$, with a mean value of $0.97 \%( \pm 0.32)$. It showed a good association with the silt, which is bolstered by the positive correlation between silt and organic carbon $(r=0.6, p<0.01)$ and negative correlation with sand $(r=-0.7, p<0.01)$.

Thus, comparatively higher values of silt and clay were observed for the middle half of the core, indicating calm and less turbulent with low-energy conditions, which facilitated the deposition of finer sediments. Hence from the results, it is clear that higher organic carbon values were observed wherever silt was high, and sand was low. The concentration of organic carbon decreased with depth in both the cores due to degradation. This is because oxygenated water percolates more quickly into coarser particles than finer particles, resulting in a faster degradation rate (Dessai \& Nayak, 2009; Fernandes \& Nayak, 2017, 2020).
Core B: The sand ranges from 46.58 to $95.52 \%$, with a mean ( \pm s.d.) value of $84.94 \%( \pm 8.54)$ (Fig. 4). Sand shows a sudden decline between the layers (11 to $17 \mathrm{~cm}$ ), which is well balanced by the increase in silt, organic carbon, and clay content in these layers. It shows a sharp increase after these layers and remains constant throughout the section. The silt ranges from 0.31 to $40.47 \%$, with a mean ( \pm s.d.) value of $9.8 \%$ $( \pm 7.07)$ and exhibits the opposite trend compared to the sand's profile. Furthermore, clay also shows the opposite trend with the sand and ranges from 0.04 to $11.27 \%$, with a mean ( \pm s.d.) value of $2.2 \%( \pm 7.07)$. Organic carbon profile matched well with the profiles of silt and clay. Increased surface area available in the silt and clay on fine grain size might have controlled organic carbon accumulation (Dessai et al., 2009; Liu et al., 2016).

Overall, core A showed a high percentage of finer fractions and organic carbon (nearly two-fold) than core $\mathrm{B}$. This is mainly because of the presence of mangroves near the core A's location. In both cores, organic carbon showed a decline with depth because of their degradation (Fernandes and Nayak, 2020).
Fig. 3 Ternary plot to classify various hydrodynamic conditions after Perjup (1988)

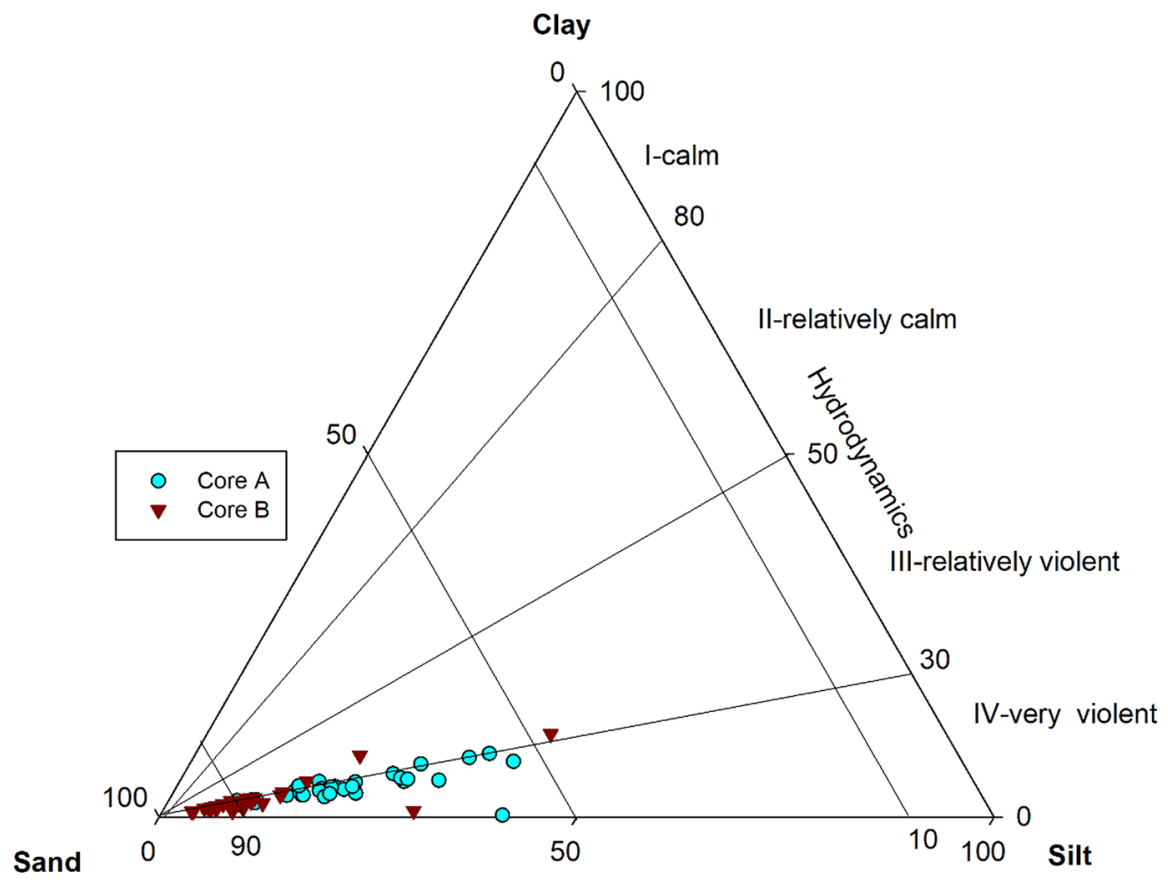


Core B

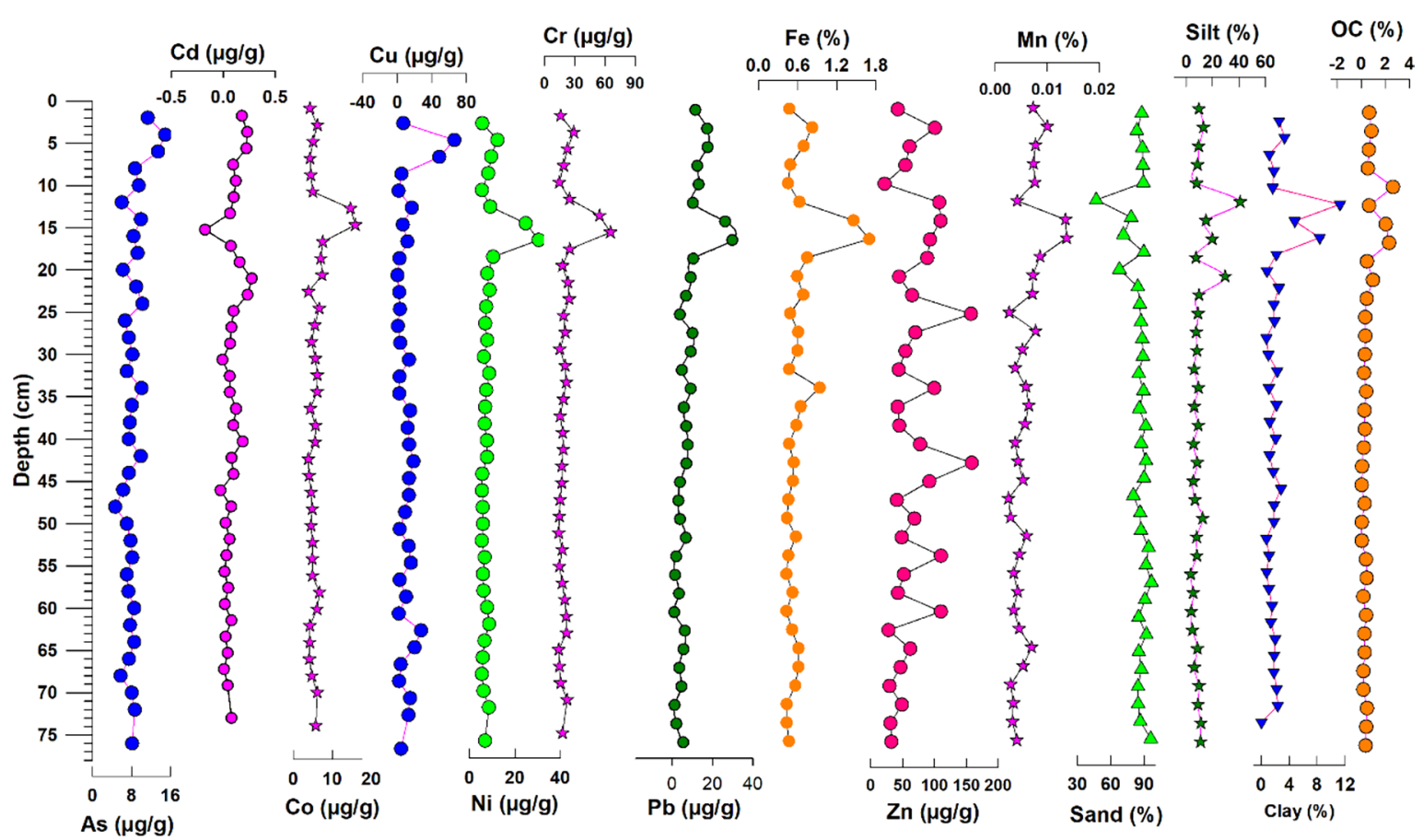

Fig. 4 Down core variations of sediment components and trace metals in core B (downstream)

Geochemistry of metals

The geochemical data for sediment core A and core B (Table 1) and down core profiles (Figs. 2 and 4) are discussed in this section.

\section{Major elements ( $\mathrm{Fe}, \mathrm{Al}$, and $\mathrm{Mn})$}

In core $\mathrm{A}$, the $\mathrm{Fe}$ concentration varied from 0.67 to $2.33 \%$ (mean $=1.46 \%$ ), and in core B (downstream estuary) between $0.43 \%$ and $1.70 \%$ (mean $=0.62 \%$ ). Similarly, $\mathrm{Al}$ varied from 2.10 to $10.27 \%$ (mean $=4.22 \%$ ), and in core B between $1.58 \%$ and $3.75 \%$ ( mean $=2.12 \%$ ). In comparison, Mn did not vary much, with a mean value of $0.01 \%$ in both the cores. A similar distribution pattern is found for Mn and Fe in cores A and B, and they showed perfect association with the rest of the elements and sediment components. A strong positive correlation between $\mathrm{Fe}$ and $\mathrm{Mn}(r=0.8, p<0.01)$ indicates their common source of origin in both the cores. This may be attributed to the form of oxyhydroxides (Fernandes $\&$ Nayak, 2015). The verticle profile of Fe follows the profile of silt up to 36-cm depth in core A and between 12 and $18 \mathrm{~cm}$ in core $\mathrm{B}$.

Further down-core, the concentration remains constant in both the cores. From the literature, Mn remains predominantly in the solution phase up to salinity 10 PSU and eventually undergoes flocculation accompanied (Dessai et al., 2009; Kerdijk \& Salomons, 1981) by precipitation at salinity 18 PSU. At the same time Fe gets precipitated at very low salinity. Similar behavior was observed in the present study for $\mathrm{Fe}$ and $\mathrm{Mn}$. As river input was less in the pre-monsoon and salinity was very high, it favored the precipitation of $\mathrm{Mn}$ at a salinity of $\sim 22$ PSU. In general, both $\mathrm{Fe}$ and $\mathrm{Mn}$ precipitate as oxides and hydroxides in the top layers of the sediments, whereas minimal accumulation takes place in the bottom layers due to dissolution and migration. This could be because of oxic conditions at the surface and suboxic to anoxic conditions down-core (Klinkhammer et al, 1982; Santschi et al., 1990; Fernandes and Nayak, 2020). 


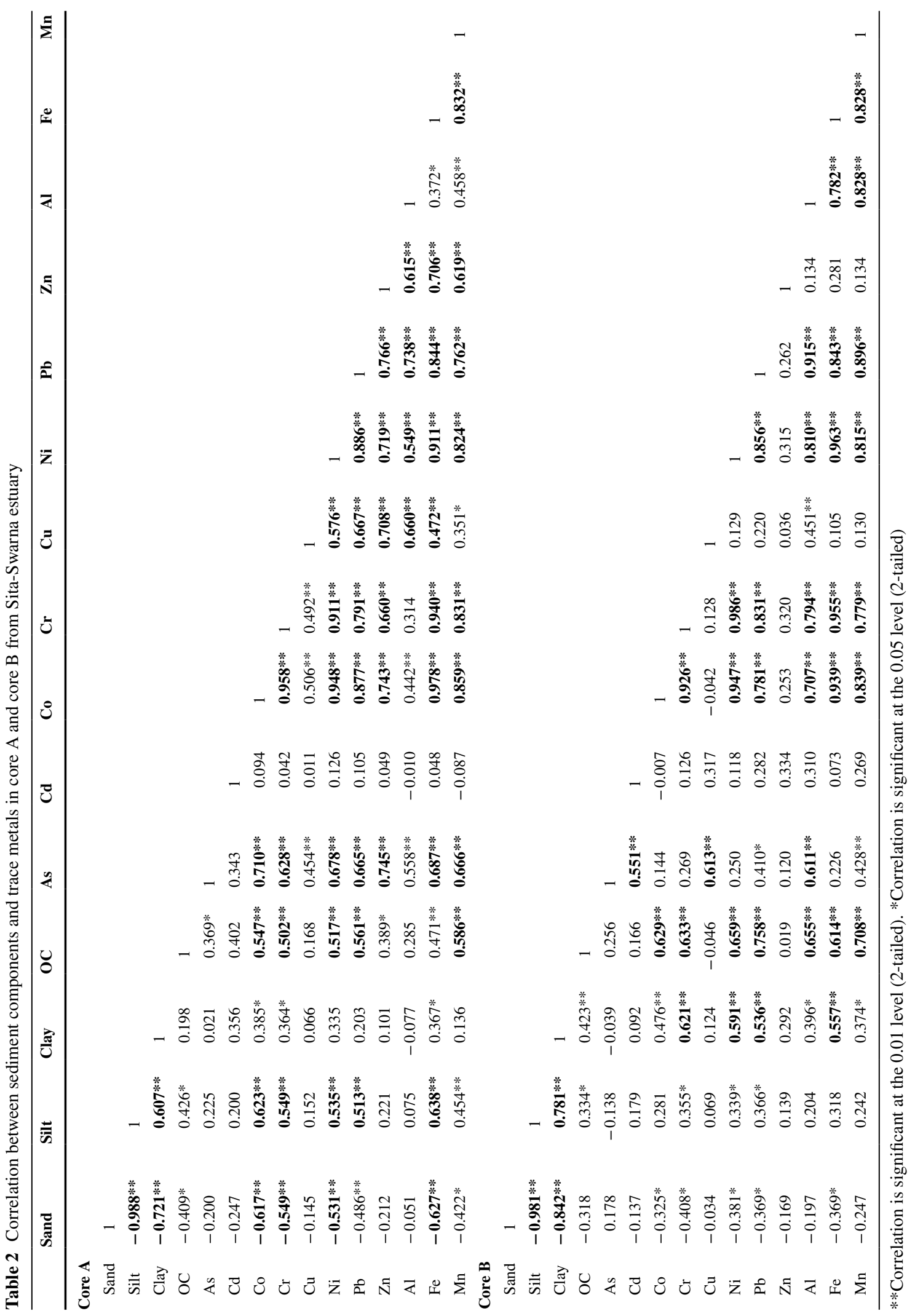


Trace elements (As, $\mathrm{Cd}, \mathrm{Ni}, \mathrm{Co}, \mathrm{Cu}, \mathrm{Cr}, \mathrm{Zn}$, and $\mathrm{Pb}$ )

In core A (Fig. 2), the elements, viz., $\mathrm{Co}, \mathrm{Cu}, \mathrm{Ni}, \mathrm{As}$, $\mathrm{Cr}$, and $\mathrm{Pb}$, showed a similar trend as silt, organic carbon, and clay in layers between 2 and $10 \mathrm{~cm}$ and 12 to $34 \mathrm{~cm}$. After $34 \mathrm{~cm}$, almost all the elements showed no significant variations which is mainly because of the increase in sand content followed by decline in the silt content. Whereas, the element $\mathrm{Cd}$ remained constant in the surface layers and showed variations in the middle slices of the core, i.e., between 26 and $38 \mathrm{~cm}$. Wherever mud fraction and organic carbon were high, trace element concentration also increased, showing the association of trace elements with the finer sediments in the form of organometallic complexes (Fernandes \& Nayak, 2015). The inference is also supported by the correlation coefficient analysis (Table 2). Other than $\mathrm{Cd}$, all the trace elements show a strong positive correlation $(>0.8)$ with $\mathrm{Fe}$ and $\mathrm{Mn}$ and moderate correlation with $\mathrm{Al}(>0.5)$. They exhibit a negative correlation with sand and good positive relation with silt and organic carbon. The strong relationship of the trace metals with $\mathrm{Fe}$ and $\mathrm{Mn}$ indicates their excellent scavenging capacity. Similarly, in core B (Fig. 4), Co, Ni, Cr, and $\mathrm{Pb}$ showed a similar trend in layers between 12 and $18 \mathrm{~cm}$. After $18 \mathrm{~cm}$, almost all the elements showed no significant variations except $\mathrm{Zn}$ which showed slight variations towards the depth. This behavior was precisely matching the profile of silt, clay, and organic carbon, which is supported by correlation coefficient analysis (Table 2). This is also supported by the results obtained from the correlation regression analysis. Majority of the trace elements show a strong positive correlation ( $>0.8$ ) with $\mathrm{Fe}$ and $\mathrm{Mn}$ and moderate correlation with $\mathrm{Al}(>0.5)$ except $\mathrm{As}, \mathrm{Cd}, \mathrm{Cu}$, and $\mathrm{Zn}$. They showed a negative correlation with sand and good positive relation with clay and organic carbon. Metals would thus be correlated with organic matter and finer fractions during the initial deposition. In contrast, metals redistribute as organic matter degrades with depth, resulting in a gradual decrease in metal concentration (Allen \& Duffy, 1998).

\section{Principal component/factor analysis}

Principal component analysis (PCA) performed for the data sets explained three principal components (PCs) for core A and three PCs for core B with a total variance of $74 \%$ and $71 \%$, respectively (Table 3 ). The experimental data was standardized initially to avoid misclassification because of the wide range in the data set. Further, sampling adequacy and the suitability of the data for performing PCA and FA were checked by Kaiser and Bartlett's sphericity tests. A high value of Kaiser-Meyer-Olkin (KMO), close to 1, indicated the sampling adequacy, and the criteria were met by the current data set $(>0.86)$. Similarly, we checked

Table 3 Principal component loadings of trace metals and sediment properties for the Sita-Swarna estuary

\begin{tabular}{|c|c|c|c|c|c|c|c|}
\hline \multirow[t]{2}{*}{ Variables } & \multicolumn{3}{|l|}{ Core A } & \multicolumn{4}{|l|}{ Core B } \\
\hline & PC1 $(46.5 \%)$ & PC $2(19.7 \%)$ & PC $3(9.7 \%)$ & PC1 $(37.6 \%)$ & PC $2(16.6 \%)$ & PC $3(14.0 \%)$ & PC $4(8.0 \%)$ \\
\hline Sand & -0.127 & -0.944 & 0.020 & -0.193 & -0.920 & -0.111 & 0.052 \\
\hline Silt & 0.100 & 0.912 & -0.053 & 0.121 & 0.906 & 0.163 & -0.085 \\
\hline Clay & 0.191 & 0.646 & 0.148 & 0.195 & 0.909 & 0.051 & 0.013 \\
\hline $\mathrm{OC}$ & -0.076 & 0.756 & 0.038 & -0.008 & 0.180 & 0.826 & -0.058 \\
\hline As & 0.603 & -0.198 & 0.687 & -0.134 & -0.353 & -0.255 & 0.479 \\
\hline $\mathrm{Cd}$ & -0.077 & 0.113 & 0.969 & -0.037 & -0.135 & 0.179 & 0.827 \\
\hline Co & 0.918 & 0.377 & 0.021 & 0.919 & -0.054 & 0.222 & -0.066 \\
\hline $\mathrm{Cr}$ & 0.964 & 0.127 & 0.071 & 0.839 & 0.375 & -0.032 & 0.159 \\
\hline $\mathrm{Cu}$ & 0.224 & 0.389 & -0.029 & -0.334 & 0.290 & -0.360 & -0.046 \\
\hline $\mathrm{Ni}$ & 0.866 & 0.384 & 0.039 & 0.857 & 0.326 & 0.188 & 0.051 \\
\hline $\mathrm{Pb}$ & 0.797 & 0.496 & -0.012 & 0.144 & 0.398 & 0.771 & -0.049 \\
\hline $\mathrm{Zn}$ & 0.320 & 0.510 & -0.051 & 0.295 & 0.286 & -0.262 & 0.726 \\
\hline $\mathrm{Fe}$ & 0.965 & 0.147 & 0.116 & 0.946 & 0.202 & 0.129 & -0.025 \\
\hline $\mathrm{Mn}$ & 0.877 & -0.070 & -0.020 & 0.471 & -0.097 & 0.749 & -0.046 \\
\hline
\end{tabular}


Fig. 5 Loading plot for core A raised in Swarna estuary (upstream)

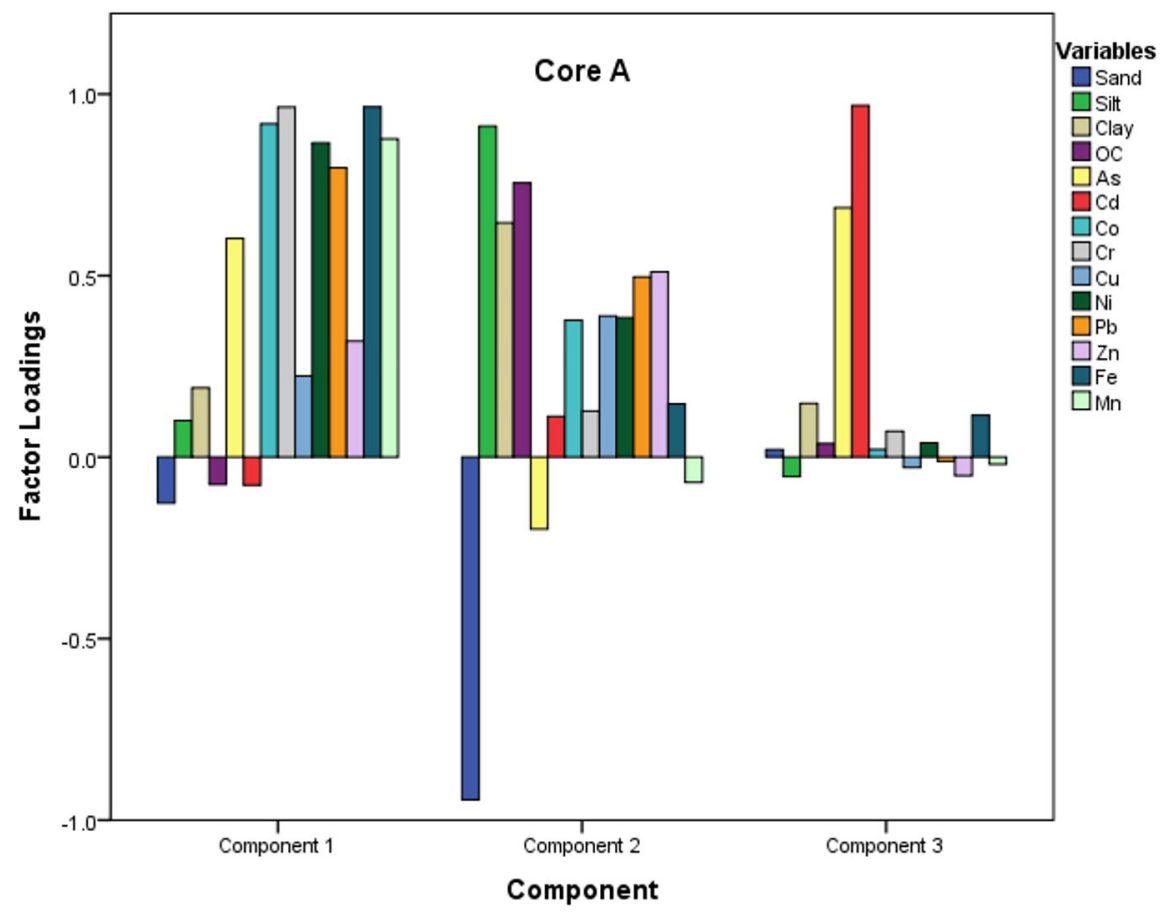

the correlation matrix for the dataset and found a significance level of 0 , indicating a significant relationship between the variables. The PCA data helped to understand the metal distribution pattern and categorize the variables with important significance.
Furthermore, to provide a simple visualization of the data (Figs. 5 and 6), PCA is described via loadings and score plots. The first PC in core A accounted for $46.5 \%$ and showed high positive loadings $>0.7$ ) for elements such as $\mathrm{Co}, \mathrm{Cr}, \mathrm{Ni}, \mathrm{Pb}, \mathrm{Fe}$, and $\mathrm{Mn}$. Metals

Fig. 6 Loading plot for core B raised in Swarna estuary (downstream)

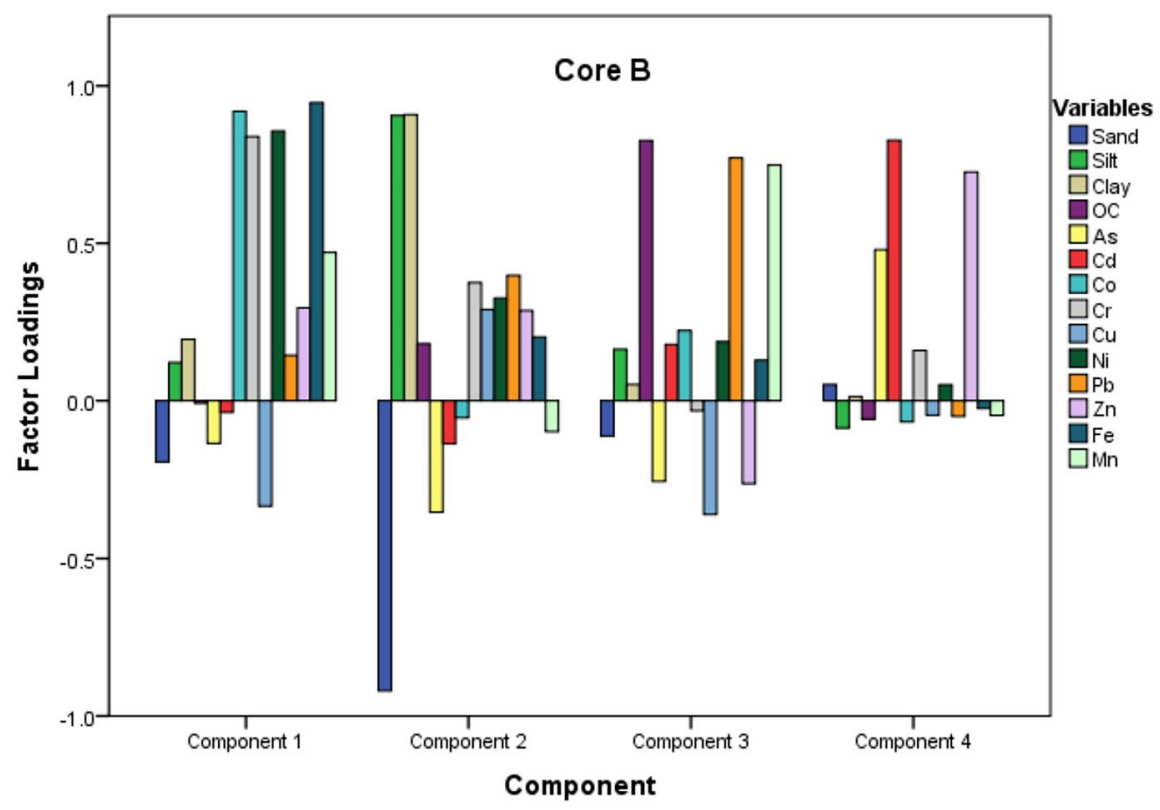


Table 4 Enrichment factor (Ergin et al., 1991) and $I_{\text {geo }}$ (Muller, 1969) values to assess sediment quality

\begin{tabular}{lllll}
\hline EF classes & Sediment quality & $I_{\text {geo }}$ & $I_{\text {geo }}$ class & Sediment quality \\
\hline EF $<1$ & No enrichment & $0-0$ & 0 & Unpolluted \\
EF $<3$ & Minor enrichment & $0-1$ & 1 & Unpolluted to moderately polluted \\
EF 3-5 & Moderate enrichment & $1-2$ & 2 & Moderately polluted \\
EF 5-10 & Moderately severe enrichment & $2-3$ & 3 & Moderately to highly polluted \\
EF 10-25 & Severe enrichment & $3-4$ & 4 & Highly polluted \\
EF 25-50 & Extremely severe enrichment & $4-5$ & 5 & Highly to very highly polluted \\
& & $5-6$ & $>5$ & Very highly polluted \\
\hline
\end{tabular}

such as $\mathrm{Zn}, \mathrm{Cd}$, and $\mathrm{Cu}$ showed very weak loadings in these components. We have named this factor as the "Fe-Mn oxide controlled factor." Thus both natural and anthropogenic sources may be attributed to PC1. The second PC accounted for $19.7 \%$ of the total variance and showed a strong association of silt, clay, and OC with high positive loading ( $>0.7)$. This factor may be called an "organic matter controlled factor." In contrast, sand showed strong negative loading $(-0.9)$, with all the other elements showing very weak loadings to sediment properties. Hence, we can conclude that only natural sources control the variations in PC2. The third component showed the most negligible variance and loaded with only two variables, As and $\mathrm{Cd}(>0.6)$, which could be because of the anthropogenic sources.
In core B (Fig. 6), PC1 accounted for $37.6 \%$, followed by high positive loadings $(>0.7)$ for elements such as $\mathrm{Co}, \mathrm{Cr}, \mathrm{Ni}$, and $\mathrm{Fe}$. Whereas $\mathrm{Cu}, \mathrm{Zn}$, and $\mathrm{Pb}$ showed no association with all other metals, and their weak loading in PC1 indicates a different source of origin.

Additionally, PC2 (16.6\% variance) and PC3 (14.0\% variance) have strong positive loadings for clay, silt, and OC and Mn, respectively, by representing the pure lithogenic origin. Strong positive loadings dominated PC4 (8.0\%) with Zn and Cd. Natural and anthropogenic sources may be attributed to variations in PC1 and $\mathrm{PC} 4$ in core $\mathrm{B}$, while natural sources purely control $\mathrm{PC} 2$ and $\mathrm{PC} 3$.
Fig. 7 Normalized EF values in the sediments of Sita-Swarna estuary

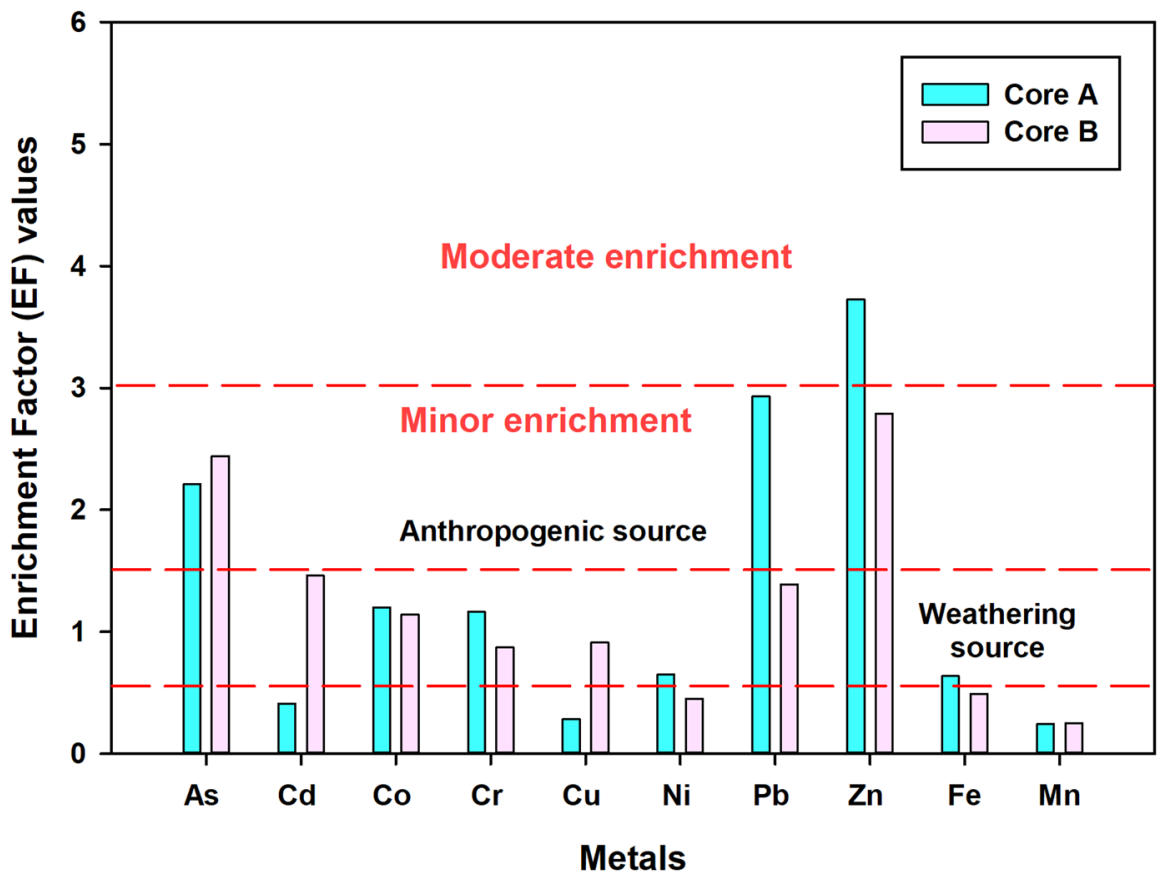



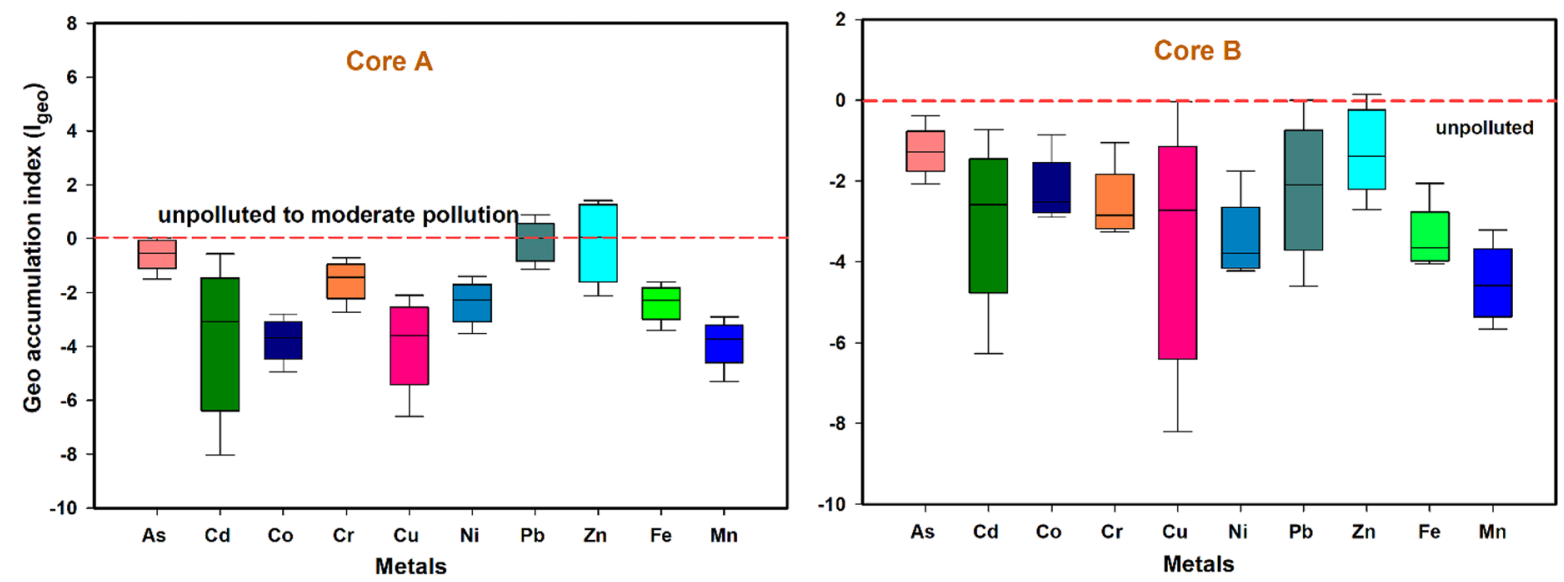

Fig. 8 Box plots representing the $I_{\text {geo }}$ values in the sediments of Sita-Swarna estuary

\section{Quality assessment of the sediments}

Enrichment factor (EF)

According to Ergin et al. (1991), enrichment values between 0.5 and 1.5 indicate the natural origin, and values $>1.5$ indicate anthropogenic origin. Based on the EF values obtained for the present study, results were interpreted using the standard values given in Table 4 . The EF values estimated for the dataset followed the order of $\mathrm{Zn}>\mathrm{Pb}>\mathrm{As}$ $>\mathrm{Co}>\mathrm{Cr}>\mathrm{Ni}>\mathrm{Fe}>\mathrm{Cd}>\mathrm{Cu}>\mathrm{Mn}$. In core $\mathrm{A}$, we found comparatively higher $\mathrm{EF}$ values vis-a-vis core B (Fig. 7), primarily due to the high percentage of finer fractions. Mean concentrations of $\mathrm{Co}$, $\mathrm{Cr}, \mathrm{Ni}, \mathrm{Pb}, \mathrm{Zn}$, and $\mathrm{Fe}$ were higher in core $\mathrm{A}$ than core $\mathrm{B}$ for the world average shale. Closeness to urban areas, harbor, movement of boats, discharge of municipal waste, and surface runoff are the primary sources of these metals. There was negligible enrichment in the $\mathrm{EF}$ values for $\mathrm{Fe}, \mathrm{Mn}, \mathrm{Ni}$, and $\mathrm{Cu}$, whereas $\mathrm{As}, \mathrm{Co}, \mathrm{Pb}, \mathrm{Cr}, \mathrm{Cd}$, and $\mathrm{Zn}$ showed mild to moderate enrichment. Hence, continuous pollution monitoring of the marine water bodies and sediment quality will help us to know the present contamination level. Also, suitable preventive measures can be taken to prevent further damage the sedimentary environment.

\section{Geoaccumulation index $\left(\mathrm{I}_{\text {geo }}\right)$}

$I_{\text {geo }}$ values estimated for $\mathrm{Zn}, \mathrm{As}, \mathrm{Pb}, \mathrm{Co}, \mathrm{Cu}, \mathrm{Cr}, \mathrm{Fe}$, $\mathrm{Ni}, \mathrm{Cd}$, and $\mathrm{Mn}$ were less than zero, suggesting that the site is not polluted with these metals (Fig. 8).

Table 5 Potential ecological risk indices and toxicity response indices based on Hakanson (1980)

\begin{tabular}{|c|c|c|c|c|c|c|c|c|c|}
\hline \multicolumn{3}{|c|}{$\left({ }^{i} E_{r}\right)$ and RI based on Hakanson (1980) } & \multicolumn{7}{|c|}{$\begin{array}{l}\text { Potential ecological risk indices for individual metal }\left({ }^{i} E_{r}\right)-\text { for the } \\
\text { current study }\end{array}$} \\
\hline \multirow[t]{2}{*}{ Potential $\left({ }^{i} E_{r}\right)$} & \multirow[t]{2}{*}{ Toxicity (RI) } & \multirow[t]{2}{*}{ Ecological risk level } & \multirow[t]{2}{*}{ Elements } & \multicolumn{3}{|c|}{ Core A } & \multicolumn{3}{|c|}{ Core B } \\
\hline & & & & Mean & Min & Max & Mean & Min & $\operatorname{Max}$ \\
\hline${ }^{i} E_{r}<40$ & $\mathrm{RI}<150$ & Low risk & As & 10.84 & 5.29 & 15.28 & 6.40 & 3.57 & 11.46 \\
\hline $40<{ }^{i} E_{r}<80$ & $150<\mathrm{RI}<300$ & Moderate risk & $\mathrm{Cd}$ & 6.43 & 0.17 & 30.43 & 9.43 & 0.59 & 27.21 \\
\hline $80<{ }^{i} E_{r}<160$ & $300<\mathrm{RI}<600$ & Considerable risk & $\mathrm{Cr}$ & 1.13 & 0.45 & 1.83 & 0.47 & 0.31 & 1.45 \\
\hline $160<{ }^{i} E_{r}<320$ & & High risk & $\mathrm{Cu}$ & 0.73 & 0.08 & 1.73 & 1.26 & 0.03 & 7.32 \\
\hline \multirow[t]{4}{*}{${ }^{i} E_{r}<320$} & $600<\mathrm{RI}$ & Very high risk & $\mathrm{Ni}$ & 1.63 & 0.66 & 2.83 & 0.62 & 0.40 & 2.24 \\
\hline & & & $\mathrm{Pb}$ & 7.43 & 3.40 & 13.88 & 2.01 & 0.03 & 7.47 \\
\hline & & & $\mathrm{Zn}$ & 1.99 & 0.34 & 4.00 & 0.72 & 0.23 & 1.67 \\
\hline & & & (RI) & 30.19 & 10.39 & 69.98 & 20.90 & 5.16 & 58.82 \\
\hline
\end{tabular}


Potential ecological risk

In the current study, the risk index (RI) proposed by Hakanson (1980) was used to assess the potential ecological risk on the aquatic environment. The values of ecological risk coefficients $\left({ }^{i} E_{r}\right)$ for $\mathrm{As}, \mathrm{Cd}, \mathrm{Cr}, \mathrm{Cu}$, $\mathrm{Ni}, \mathrm{Pb}$, and $\mathrm{Zn}$ are presented in Table 5.

The values of ${ }^{i} E_{r}$ were lower than 40 for all the elements analyzed in the study. And, the values of RI were lower than 150 in both the cores A and B indicating low risk for the aquatic life. These results are also in good agreement with the values of $I_{\text {geo }}$, indicating less pollution in the catchment.

\section{Conclusion}

From the above study, the following conclusions can be drawn:

Core A showed a high concentration of metals than core B because of the surrounding mangroves near core A. Further, the amount of organic carbon and percentage of finer fractions was approximately two-fold higher near mangroves, highlighting the efficiency of mangroves in sequestering the trace metals. The PCA data explained three PCs for core $\mathrm{A}$ and three PCs for core B with a total variance of $76 \%$ and $77 \%$, respectively. The study revealed that $\mathrm{Fe}-\mathrm{Mn}$ oxyhydroxides and organic carbon are the two crucial factors that controlled metals' distribution in the catchment. Further, based on the $I_{\text {geo }}$ and enrichment values, the site can be categorized to show less pollution with all the metals analyzed. The $I_{\text {geo }}$ values for $\mathrm{Pb}$ and $\mathrm{Zn}$ were slightly higher in both the cores and indicate moderate pollution in the catchment. The potential ecological risk index $\left({ }^{i} E_{r}\right)$ for all metals was found to be less than 40 , and the toxicity response index (RI) was below 150 , indicating a no risk to aquatic life in the catchment. Hence the present study can be used as baseline data to monitor and protect the fragile coastal environment.

Acknowledgements AC Dinesh, Saju Varghese, and Rachna Pillai, Geological Survey of India, Mangalore are thanked for providing instrumental facilities.

Author contribution D'Souza Nishitha - conceptualization, investigation, analysis, and original draft writing. Vadakkeveedu Narayan Amrish — methodology. Kumar Arun — methodology.
Anish Kumar Warrier - reviewing and editing. Harikripa Narayana Udayashankar — editing. Keshava Balakrishna supervision, reviewing, and editing.

Funding Open access funding provided by Manipal Academy of Higher Education, Manipal. Ministry of Earth Sciences, Government of India is thanked for funding this project through its project no. MoES/CCR/PALEO-10/2015 to the corresponding author.

Data availability The datasets generated during and/or analyzed during the current study are available from the corresponding author on reasonable request.

\section{Declarations}

Ethics approval and consent to participate Not applicable.

Consent for publication Not applicable.

Conflict of interest The authors declare no competing interests.

Open Access This article is licensed under a Creative Commons Attribution 4.0 International License, which permits use, sharing, adaptation, distribution and reproduction in any medium or format, as long as you give appropriate credit to the original author(s) and the source, provide a link to the Creative Commons licence, and indicate if changes were made. The images or other third party material in this article are included in the article's Creative Commons licence, unless indicated otherwise in a credit line to the material. If material is not included in the article's Creative Commons licence and your intended use is not permitted by statutory regulation or exceeds the permitted use, you will need to obtain permission directly from the copyright holder. To view a copy of this licence, visit http://creativecommons.org/licenses/by/4.0/.

\section{References}

Ahmed, I., Mostefa, B., Bernard, A., \& Olivier, R. (2018). Levels and ecological risk assessment of heavy metals in surface sediments of fishing grounds along the Algerian coast. Marine Pollution Bulletin, 136, 322-333. https:// doi.org/10.1016/j.marpolbul.2018.09.029

Avinash, K., Jayappa, K. S., \& Vethamony, P. (2012). Evolution of Swarna estuary and its impact on braided islands and estuarine banks, Southwest coast of India. Environmental Earth Sciences, 65(3), 835-848. https://doi.org/10. 1007/s12665-011-1128-3

Alagarsamy, R. (2006). Distribution and seasonal variation of trace metals in surface sediments of the Mandovi estuary, west coast of India. Estuarine, Coastal and Shelf Science, 67(1-2), 333-339. https://doi.org/10.1016/j.ecss.2005.11. 023

Alharbi, O. M., Khattab, R. A., Ali, I., Binnaser, Y. S., \& Aqeel, A. (2019). Assessment of heavy metals contamination in the sediments and mangroves (Avicennia marina) at Yanbu 
coast, Red Sea Saudi Arabia. Marine Pollution Bulletin, 149, 110669. https://doi.org/10.1016/j.marpolbul.2019.110669

Allen, J. R. L., \& Duffy, M. J. (1998). Temporal and spatial depositional patterns in the Severn Estuary, southwestern Britain: Intertidal studies at spring-neap and seasonal scales, 1991-1993. Marine Geology, 146(1-4), 147-171. https://doi.org/10.1016/S0025-3227(97)00124-2

Atkinson, C. A., Jolley, D. F., \& Simpson, S. L. (2007). Effect of overlying water $\mathrm{pH}$, dissolved oxygen, salinity and sediment disturbances on metal release and sequestration from metal contaminated marine sediments. Chemosphere, 69(9), 14281437. https://doi.org/10.1016/j.chemosphere.2007.04.068

Bastakoti, U., Robertson, J., Marchand, C., \& Alfaro, A. C. (2019). Mangrove removal: Effects on trace metal concentrations in temperate estuarine sediments. Marine Chemistry, 216, 103688. https://doi.org/10.1016/j.marchem.2019.103688

Bingöl, D., Ay, Ü., Bozbaş, S. K., \& Uzgören, N. (2013). Chemometric evaluation of the heavy metals distribution in waters from the Dilovas1 region in Kocaeli. Turkey. Marine Pollution Bulletin, 68(1-2), 134-139. https://doi. org/10.1016/j.marpolbul.2012.12.006

Cyriac, M., Gireeshkumar, T. R., Furtado, C. M., Fathin, K. F., Shameem, K., Shaik, A., \& Balachandran, K. K. (2021). Distribution, contamination status and bioavailability of trace metals in surface sediments along the southwest coast of India. Marine Pollution Bulletin, 164, 112042. https://doi.org/10.1016/j.marpolbul.2021.112042

Dessai, D. V., Nayak, G. N., \& Basavaiah, N. (2009). Grain size, geochemistry, magnetic susceptibility: Proxies in identifying sources and factors controlling the distribution of metals in a tropical estuary, India. Estuarine, Coastal and Shelf Science, 85(2), 307-318. https://doi.org/10. 1016/j.ecss.2009.08.020

Ergin, M., Saydam, C., Baştürk, Ö., Erdem, E., \& Yörük, R. (1991). Heavy metal concentrations in surface sediments from the two coastal inlets (Golden Horn Estuary and Izmit Bay) of the northeastern Sea of Marmara. Chemical Geology, 91(3), 269-285. https://doi.org/10.1016/00092541(91)90004-B

Ergül, H. A., Varol, T., \& Ay, Ü. (2013). Investigation of heavy metal pollutants at various depths in the Gulf of Izmit. Marine Pollution Bulletin, 73(1), 389-393. https://doi.org/ 10.1016/j.marpolbul.2013.05.018

Fernandes, C., Fontaínhas-Fernandes, A., Cabral, D., \& Salgado, M. A. (2008). Heavy metals in water, sediment, and tissues of Liza saliens from Esmoriz-Paramos lagoon Portugal. Environmental Monitoring and Assessment, 136(1-3), 267275. https://doi.org/10.1007/s10661-007-9682-6

Fernandes, M. C., \& Nayak, G. N. (2015). Speciation of metals and their distribution in tropical estuarine mudflat sediments, southwest coast of India. Ecotoxicology and Environmental Safety, 122, 68-75. https://doi.org/10.1016/j.ecoenv. 2015.07.016

Fernandes, M. C., \& Nayak, G. N. (2016). Role of sediment size in the distribution and abundance of metals in tropical (Sharavati) estuary, west coast of India. Arabian Journal of Geosciences, 9(1), 33. https://link.springer.com/article/10. 1007/s12517-015-2127-6

Fernandes, M. C., \& Nayak, G. N. (2017). Geochemistry of mudflat and mangrove sedimentary environments, within tropical (Sharavati) estuary, Karnataka coast, India. https://www.researchgate.net/publication/320383144

Fernandes, M. C., \& Nayak, G. N. (2020). Depositional environment and metal distribution in mangrove sediments within middle region of tropical estuaries, Karnataka, west coast of India. Regional Studies in Marine Science, 39, 101473

Gaillardet, J., Dupré, B., \& Allègre, C. J. (1995). A global geochemical mass budget applied to the Congo Basin rivers: Erosion rates and continental crust composition. Geochimica Et Cosmochimica Acta, 59(17), 3469-3485. https://doi. org/10.1016/0016-7037(95)00230-W

Ghosh, S., Ram, S. S., Bakshi, M., Chakraborty, A., Sudarshan, M., \& Chaudhuri, P. (2016). Vertical and horizontal variation of elemental contamination in sediments of Hooghly Estuary. India. Marine Pollution Bulletin, 109(1), 539-549. https://doi.org/10.1016/j.marpolbul.2016.04.043

Gredilla, A., Stoichev, T., de Vallejuelo, S. F. O., RodriguezIruretagoiena, A., de Morais, P., Arana, G., \& Madariaga, J. M. (2015). Spatial distribution of some trace and major elements in sediments of the Cávado estuary (Esposende, Portugal). Marine Pollution Bulletin, 99(1-2), 305-311. https://doi.org/10.1016/j.marpolbul.2015.07.040

Hakanson, L. (1980). An ecological risk index for aquatic pollution control. A Sedimentological Approach. Water Research, 14(8), 975-1001. https://doi.org/10.1016/0043-1354(80)90143-8

Hu, B., Li, G., Li, J., Bi, J., Zhao, J., \& Bu, R. (2013). Spatial distribution and ecotoxicological risk assessment of heavy metals in surface sediments of the southern Bohai Bay. China. Environmental Science and Pollution Research, 20(6), 4099-4110. https://doi.org/10.1007/s11356-012-1332-z

Kerdijk, H. N., \& Salomons, W. (1981). Heavy metal cycling in the Scheldt Estuary. Delft Hydraulics Report M, 1640, M1736.

Klinkhammer, G., Heggie, D. T., \& Graham, D. W. (1982). Metal diagenesis in oxic marine sediments. Earth and Planetary Science Letters, 61(2), 211-219. https://doi.org/ 10.1016/0012-821X(82)90054-1

Liu, J., Yin, P., Chen, B., Gao, F., Song, H., \& Li, M. (2016). Distribution and contamination assessment of heavy metals in surface sediments of the Luanhe River Estuary, northwest of the Bohai Sea. Marine Pollution Bulletin, 109(1), 633-639. https://doi.org/10.1016/j.marpolbul.2016.05.020

Liu, J., Song, J., Yuan, H., Li, X., Li, N., \& Duan, L. (2019). Trace metal comparative analysis of sinking particles and sediments from a coastal environment of the Jiaozhou Bay, North China: Influence from sediment resuspension. Chemosphere, 232, 315-326. https://www.sciencedirect.com/ science/article/pii/S0045653519309944

Mitra, S., Sarkar, S. K., Raja, P., Biswas, J. K., \& Murugan, K. (2018). Dissolved trace elements in Hooghly (Ganges) River Estuary, India: Risk assessment and implications for management. Marine Pollution Bulletin, 133, 402-414. https://doi.org/10.1016/j.marpolbul.2018.05.057

Muller, G. (1969). Index of geoaccumulation in sediments of the Rhine River. GeoJournal, 2, 108-118.

Mokwe-Ozonzeadi, N., Foster, I., Valsami-Jones, E., \& McEldowney, S. (2019). Trace metal distribution in the bed, bank, and suspended sediment of the Ravensbourne River and its implication for sediment monitoring in an urban river. Journal of soils and sediments, 19(2), 946-963. https:// link.springer.com/article/10.1007/s11368-018-2078-0 
Nasnodkar, M. R., \& Nayak, G. N. (2015). Processes and factors regulating the distribution of metals in mudflat sedimentary environment within tropical estuaries. India. Arabian Journal of Geosciences, 8(11), 9389-9405. https:// doi.org/10.1007/s12517-015-1823-6

Nishitha, D., Akshitha, V., Arun, K., Amrish, V. N., Praveenkumarreddy, Y., Khare, N., Udayashankar, H. N., Manjunatha, B. R., \& Balakrishna, K. (2021). Dissolved carbon and silica fluxes from Kali, Sharavati and Sita-Swarna rivers, Southwestern India. Journal of Environmental Management, 286: 112273

Nishitha, D., Praveenkumarreddy, Y., Khare, N., et al. (2019). Spatio-temporal variability of trace metals and major ions in a small tropical river, southwest coast of India. Environmental Monitoring and Assessment, 191, 698. https://doi. org/10.1007/s10661-019-7852-y

Pejrup, M. (1988). The triangular diagram used for classification of estuarine sediments: anew approach. In: de Boer, P.L., van Gelder, A., Nios, S.D. (Eds.), Tide - InfluencedSedimentary Environments and Facies. Reidel, Dordrecht. 289-300

Prajith, A., Rao, V. P., \& Chakraborty, P. (2016). Distribution, provenance and early diagenesis of major and trace metals in sediment cores from the Mandovi estuary, western India. Estuarine, Coastal and Shelf Science, 170, 173-185. https://doi.org/10.1016/j.ecss.2016.01.014

Santschi, P., Höhener, P., Benoit, G., \& Buchholtz-ten Brink, M. (1990). Chemical processes at the sediment-water interface. Marine Chemistry, 30, 269-315. https://doi.org/ 10.1016/0304-4203(90)90076-O

Satapathy, D. R., \& Panda, C. R. (2015). Spatio-temporal distribution of major and trace metals in estuarine sediments of Dhamra, Bay of Bengal, India-Its environmental significance. Environmental Monitoring and Assessment, 187, 4133. https://doi.org/10.1007/s10661-014-4133-7

Suja, S., Kessarkar, P. M., Fernandes, L. L., Kurian, S., \& Tomer, A. (2017). Spatial and temporal distribution of metals in suspended particulate matter of the Kali estuary, India. Estuarine, Coastal and Shelf Science, 196, 10-21. https://doi.org/10.1016/j.ecss.2017.06.024

Tavakoly Sany, S. B., Hashim, R., Rezayi, M., et al. (2014). A review of strategies to monitor water and sediment quality for a sustainability assessment of marine environment. Environmental Science and Pollution Research 21, 813-833. https://doi.org/10.1007/s11356-013-2217-5
Turekian, K. K., \& Wedepohl, K. H. (1961). Distribution of the elements in some major units of the earth's crust. Geological Society of America Bulletin, 72(2), 175-192. https:// doi.org/10.1130/0016-7606(1961)72[175:DOTEIS]2.0. $\mathrm{CO} ; 2$

Tripti, M., Gurumurthy, G. P., Balakrishna, K., \& Chadaga, M. D. (2013). Dissolved trace element biogeochemistry of a tropical river, Southwestern India. Environmental Science and Pollution Research, 20(6), 4067-4077. https://doi.org/ 10.1007/s11356-012-1341-y

Warrier, A. K., Pednekar, H., Mahesh, B. S., Mohan, R., \& Gazi, S. (2016). Sediment grain size and surface textural observations of quartz grains in late quaternary lacustrine sediments from Schirmacher Oasis, East Antarctica: Paleo environmental significance. Polar Science, 10(1), 89-100. https://doi.org/10.1016/j.polar.2015.12.005

Xavier, D., dos Santos, V. F., de Miranda, A. G. O., \& Berrêdo, J. F. (2020). Determination of background geochemistry of an Amazon estuary: The Cuñaní Estuary-Amapá. Marine Pollution Bulletin, 155, 111144. https://doi.org/10.1016/j. marpolbul.2020.111144

Zahra, A., Hashmi, M. Z., Malik, R. N., \& Ahmed, Z. (2014). Enrichment and geo-accumulation of heavy metals and risk assessment of sediments of the Kurang Nallah-Feeding tributary of the Rawal Lake Reservoir, Pakistan. Science of the Total Environment, 470, 925-933. https://doi.org/10. 1016/j.scitotenv.2013.10.017

Zhao, G., Ye, S., Yuan, H., Ding, X., \& Wang, J. (2017). Surface sediment properties and heavy metal pollution assessment in the Pearl River Estuary. China. Environmental Science and Pollution Research, 24(3), 2966-2979. https:// doi.org/10.1016/S1001-0742(11)60783-3

Zhang, J., \& Gao, X. (2015). Heavy metals in surface sediments of the intertidal Laizhou Bay, Bohai Sea, China: Distributions, sources and contamination assessment. Marine Pollution Bulletin, 98(1-2), 320-327. https://doi. org/10.1016/j.marpolbul.2015.06.035

Publisher's Note Springer Nature remains neutral with regard to jurisdictional claims in published maps and institutional affiliations. 